\title{
PENGEMBANGAN DESAIN STRUKTUR SILINDER BILAH ROTAN DENGAN TEKNIK LILIT
}

\author{
Alivia Syam \\ Institut Teknologi Bandung \\ e-mail: aliviasyam@gmail.com \\ Andar Sriwarno \\ Institut Teknologi Bandung \\ e-mail: andarbugs@yahoo.com \\ Prabu Wardono \\ Institut Teknologi Bandung \\ e-mail: pwardono@yahoo.com
}

\begin{abstract}
ABSTRAK
Saat ini produk rotan Indonesia banyak yang dibuat dari modul konstruksi, modul anyaman, modul joint system dari waktu ke waktu. Banyak masyarakat cenderung melihat produk rotan adalah produk yang monoton dan ketinggalan jaman. Menanggapi permasalahan tersebut, diperlukan sebuah inovasi yang dapat mengubah wujud visual produk rotan dengan menambah variasi teknik-teknik tertentu di dalamnya. Dari berbagai eksperimen yang telah dilakukan di Indonesia, bagian batang merupakan yang paling sering digunakan dengan berbagai macam perlakuan dan metode. Oleh sebab itu, dapat dikatakan bahwa batang rotan adalah bagian yang memiliki potensi paling besar untuk dieksplorasi. Rotan batang pun selain dilengkungkan (bending) dapat pula diberikan perlakuan lain, yaitu dengan cara dibelah dengan tebal yang bervariasi tergantung dengan kebutuhan. Di pasaran, rotan yang diberikan perlakuan tersebut dikenal dengan istilah bilah rotan (strip rattan). Sayangnya, bilah rotan ini tidak dijual bebas di pasaran seperti layaknya bilah bambu, untuk mendapatkannya harus request atau pesan terlebih dahulu oleh para pengrajin. Namun positifnya, menjadi lebih mudah untuk mendapatkan ketebalan bilah rotanyang sesuai dengan kebutuhan. Bilah rotan yang jarang digunakan oleh para pelaku rotan sebagai bahan baku, menjadikan salah satu solusi terhadap permasalahan rotan yang terjadi saat ini. Dengan adanya pengembangan desain terhadap bilah rotan ini, maka diharapkan produk rotan bisa menjadi lebih berkembang variasi tekniknya. Penelitian ini dilakukan dengan metode eksperimen terhadap bilah rotan yang menggunakan teknik twist bending, yaitu teknik melengkungkan sekaligus melilitkan bilah rotan terhadap cetakannya. Rotan yang digunakan adalah rotan Manau, dengan ketebalan bilah rotan $3 \mathrm{~mm}$ dan $5 \mathrm{~mm}$, dan dibuat dengan diameter cetakan $8 \mathrm{~cm}$ dan $15 \mathrm{~cm}$. Dari eksperimen ini menghasilkan struktur silinder yang dibuat dari bilah rotan dengan cara dililit. Hasil penemuan ini dapat digunakan dan dimanfaatkan lebih jauh untuk kebutuhan-kebutuhan desain yang memerlukan struktur silinder.
\end{abstract}

Kata Kunci : Bilah Rotan, Twist Bending, Struktur Silinder 
Alivia Syam, Andar Sriwarno, Prabu Wardono, Pengembangan Desain Struktur Silinder Bilah Rotan Dengan Teknik Lilit

ABSTRAK

Currently many Indonesian rattan products are made of construction modules, woven modules, connection system modules from time to time. Many people who see rattan products are monotonous and outdated. Responding to the problem, an innovation is needed that can change the visual form of the product with certain techniques. From various experiments that have been carried out in Indonesia, the part which is the most common with various kinds of services and methods. Therefore, it can be said that the rattan rod is the part that has the greatest potential to be explored. Rattan stems besides being bent can also be given in other ways, namely by dividing the length which varies depending on the needs. In the market, rattan which is given treatment is known as the rattan bar (rattan strip). Unfortunately, this rattan blade is not sold freely on the market like bamboo, to match it must ask for a letter from the craftsmen. But positively, it becomes easier to get the thickness of the strip that suits your needs. The rattan bar, which the rattan players call raw material, is one of the solutions to rattan that is happening now. With the development of the design of this rattan blade, it is expected that rattan products can be more than techniques. This research was carried out with an experimental method of rattan blades which used a twist bending technique, which is a curved technique while wrapping a rattan blade against the mold. Rattan which is Manau rattan, with a thickness of $3 \mathrm{~mm}$ and $5 \mathrm{~mm}$ strips, and made with a mold diameter of $8 \mathrm{~cm}$ and $15 \mathrm{~cm}$. From this writing, use a cylindrical structure made from rattan blades in a way wrapped around. The results of this invention can be used further for design requirements that meet the cylinder structure.

Keywords: Rattan Strips, Twist Bending, Cylinder Structure

\section{PENDAHULUAN}

Sejak 30 tahun terakhir, Indonesia merupakan pemasok $70-85 \%$ bahan baku rotan dunia (Jasni, Kalima, Damayanti, 2012). Ahli Rotan, Janumirno (2000) pun mengatakan, bahwa pada abad ke-18, Indonesia telah menjadi pelopor dalam penyediaan produk rotan dunia, bahkan $80 \%$ kebutuhan rotan dunia dipasok oleh Indonesia (Marizar, 2007). Hal tersebut juga diungkapkan oleh Peter Hirchberger (2011), yaitu rotan sebagai sumber devisa yang sangat besar bagi negara, karena Indonesia merupakan negara terbesar penghasil rotan mentah di dunia (Triwahyuni dan Artha, 2014). Produk rotan yang dihasilkan Indonesia baik untuk pasar lokal maupun ekspor didominasi oleh produk mebel seperti meja, kursi, lemari, dan sebagainya. Hal tersebut juga sesuai dengan penelitian yang dilakukan oleh Tjiasmanto dkk (2017), yaitu mebel yang ditujukan untuk kebutuhan residensial merupakan jenis produk rotan yang diproduksi dan beredar di pasaran. Namun perusahaan pengimpor rotan dari Jepang mengatakan, bahwa produk mebel rotan asal Indonesia dalam perkembangannya mengalami penurunan kualitas, desain kurang kreatif, dan supply yang lambat (Kemendag, 2014). Hal tersebut dapat dikarenakan banyak potensi yang dimiliki oleh rotan, namun belum seluruhnya terjamah oleh para pelaku rotan, sehingga diperlukan sebuah inovasi dari faktor teknik dan juga materialnya. Inovasi tersebut juga dapat mendorong Indonesia untuk berkomitmen membangun pasar rotan yang lebih baik, mewujudkan lebih banyak lapangan pekerjaan, dan meraih kembali kejayaan ekspor produknya. Solusi tersebut juga sesuai dengan salah satu visi misi Making Indonesia 4.0, yaitu gerakan pemerintah untuk meningkatkan aktivitas penelitian, pengembangan, desain dan inovasi untuk dapat berkontribusi mendorong inisiatif penguasaan dan pengembangan teknologi 
Vol. 5, No. 2, April 2018

di masa datang (Kemenperin, 2018).

Salah satu inovasi dari faktor material adalah dengan menggunakan batang rotan sebagai bahan utamanya. Rotan batang pun selain digunakan secara utuh masih dapat diberikan perlakuan lain, salah satunya yaitu dengan cara dibelah dengan tebal bervariasi tergantung dengan kebutuhan, seperti $3 \mathrm{~mm}, 5 \mathrm{~mm}, 7 \mathrm{~mm}$. Pengrajin rotan pun sering menyebut jenis rotan ini dengan bilah rotan (strip rattan). Sayangnya, bilah rotan tidak dijual bebas di pasaran, untuk mendapatkannya harus request atau pesan terlebih dahulu oleh para pengrajin. Namun positifnya, menjadi lebih mudah untuk mendapatkan ketebalan yang sesuai dengan kebutuhan.

Inovasi teknik yang diperlukan adalah inovasi yang mampu menambah variasi dari modul konstruksi, modul anyaman, modul joint system yang selama ini telah diaplikasikan pada produk-produk rotan. Salah satu inovasi yang dapat dilakukan adalah dengan mengembangkan sebuah modul yang dapat mengubah wujud visual produk rotan dengan menambah variasi teknik-teknik tertentu di dalamnya. Sedangkan teknik yang dapat dikembangkan adalah dengan cara menggabungkan teknik lilit (bending) dan lilit (twist) secara bersamaan menjadi sebuah modul, yang untuk selanjutnya akan disebut sebagai teknik twist bend- ing.

Tujuan penelitian ini adalah untuk memberikan variasi terhadap inovasi teknik dan material yaitu mengaplikasikan teknik twist bending pada bilah rotan, yang nantinya dapat diterapkan pada produk rotan. Sehingga dalam pencapaian akhirnya teknik ini dapat dijadikan alternatif desain dalam pembuatan produk rotan yang membutuhkan sebuah struktur didalamnya dengan tampilan baru, yaitu dengan material sebuah lembaran bilah rotan.

\section{KONSEP DESAIN}

Penelitian ini menggunakan rotan manau, karena termasuk rotan kelas I (Sangat Tahan Bubuk) yang karakteristiknya sangat elastis, bahkan setelah dikukus mampu di-bending dengan diameter $<10 \mathrm{~cm}$ (Jasni, Kalima, Damayanti, 2012). Sehingga hal tersebut sesuai dengan konsep penelitian ini, yaitu desain yang menuntut keelastisitas tinggi yang mampu dilengkungkan atau di-bending dengan diameter tertentu. Rotan manau yang digunakan pada eksperimen ini adalah yang berdiameter $3 \mathrm{~cm}, 4 \mathrm{~cm}$, dan $5 \mathrm{~cm}$. Kemudian rotan ini akan dibelah menggunakan mesin sehingga menghasilkan sebuah lembaran, yang selanjutnya pada penulisan ini akan disebut dengan bilah rotan.

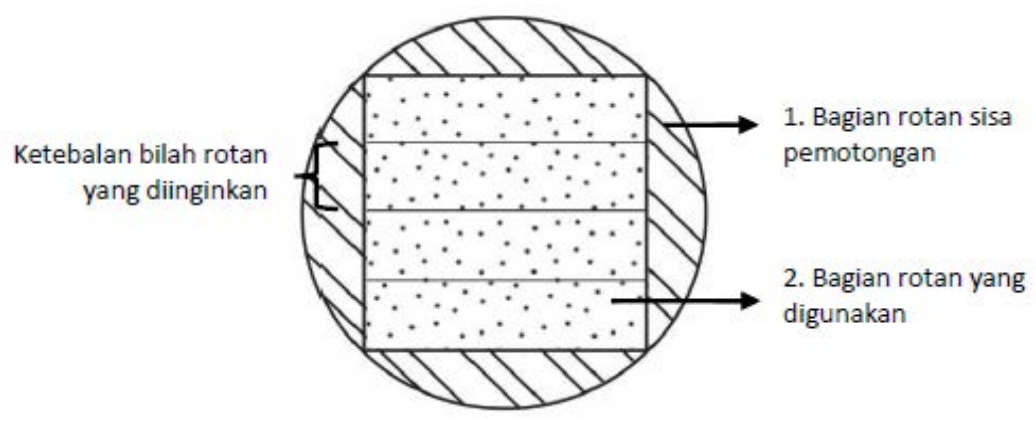

Gambar 1. Sketsa bagian rotan yang digunakan untuk bilah rotan 
Alivia Syam, Andar Sriwarno, Prabu Wardono, Pengembangan Desain Struktur Silinder Bilah Rotan Dengan Teknik Lilit

Bilah rotan terbuat dari rotan utuh yang dibelah menjadi pipih dengan ketebalan yang dapat disesuaikan. Bagian rotan yang diambil adalah bagian tengahnya, namun bagian pinggir rotan dibelah terlebih dahulu. Gambar III.I menjelaskan, bahwa dalam batang rotan utuh dapat menghasilkan beberapa bilah rotan, semakin tipis ketebalannya akan semakin banyak jumlah didapatkan, begitu pun sebaliknya.

\section{PEMBahaSAN}

A. Alur Eksperimen

Penelitian ini dilakukan dengan metode eksperimen, dengan didahului oleh pra eksperimen sebelumnya. Tujuannya adalah untuk membuktikan bahwa bilah rotan mampu direalisasikan sesuai konsep, yaitu dililit dan di-bending sehingga menghasilkan sebuah modul silinder atau twister. Selain itu guna mengetahui hambatan-hambatan yang terjadi selama proses eksperimen dan trik yang digunakan sebagai ben- tuk dari solusi hambatan tersebut.

Konsep desain pada penelitian ini adalah seperti yang telah diulas sebelumnya, yaitu membuat sebuah modul dengan menerapkan teknik twist bending pada bilah rotan. Bilah rotan yang digunakan terdiri dari rotan utuh yang berdiameter, yaitu $3 \mathrm{~cm}, 4 \mathrm{~cm}$ dan $5 \mathrm{~cm}$. Tabel 1 menjelaskan, masing-masing rotan tersebut akan dibuat diameter silinder yang berbeda, yaitu rotan $3 \mathrm{~cm}$ akan dibuat bilah rotan dengan tebal $3 \mathrm{~mm}$ dan dibuat modul twister berdiameter $10 \mathrm{~cm}$, rotan $4 \mathrm{~cm}$ akan dibuat bilah rotan dengan tebal $5 \mathrm{~mm}$ dan dibuat modul twister berdiameter $15 \mathrm{~cm}$, serta rotan $5 \mathrm{~cm}$ akan dibuat bilah rotan dengan tebal $5 \mathrm{~mm}$ dan dibuat modul twister berdiameter $20 \mathrm{~cm}$. Oleh karena itu, pada prosesnya akan dibutuhkan sebuah cetakan yang berguna untuk tempat merekatkan bilah rotan. Cetakan tersebut berdiameter kurang lebih sama dengan diameter silinder yang diinginkan.

Tabel 1. Ukuran yang digunakan pada eksperimen

\begin{tabular}{ccc} 
Rotan & Tebal Bilah Rotan & Diameter Silinder \\
\hline $50 \mathrm{~mm}$ & $5 \mathrm{~mm}$ & $20 \mathrm{~cm}$ \\
\hline $40 \mathrm{~mm}$ & $5 \mathrm{~mm}$ & $15 \mathrm{~cm}$ \\
\hline $30 \mathrm{~mm}$ & $3 \mathrm{~mm}$ & $10 \mathrm{~cm}$
\end{tabular}
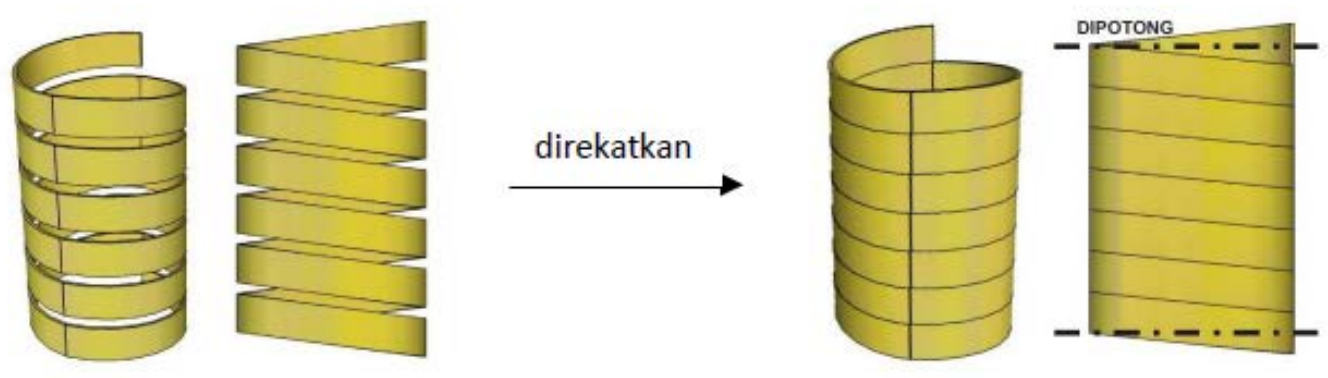

Gambar 2. Sketsa Modul Twister 
Vol. 5, No. 2, April 2018

B. Karakter Bilah Rotan

Bilah rotan adalah batang rotan yang telah dibuang bagian kulit dan daging terluarnya, menjadi bentuk segi empat, yang kemudian bagian tersebut dibelah sesuai dengan ketebalan yang diinginkan. Adapun potensi-potensi bilah rotan adalah sebagai berikut.

- Bilah rotan mampu menciptakan citra, identitas, dan nilai baru tentang rotan.

- Value of interest yang dimiliki bilah rotan dapat menjadi solusi tentang kejenuhan di produk rotan saat ini

- Bilah rotan mampu dilengkungkan (bending) dengan diameter lebih kecil daripada rotan batang utuh.

- Bilah rotan memiliki elastisitas yang tidak kalah dari rotan utuh.

- Bilah rotan mampu dibentuk menjadi suatu bentuk lain, yang tidak mampu dibentuk oleh rotan utuh.

- Bilah rotan mampu dirapatkan antar sisinya yang apabila direkatkan dapat menahan zat padat dari rembesan atau tumpahan. Bahkan karena sifatnya yg dapat dirapatkan, dengan lem dan finishing zat tertentu, dapat tahan dari rembesan air.

Namun untuk pembuatan bilah rotan terdapat beberapa kekurangan, yaitu menyisakan bahan baku yang cukup besar, yaitu sekitar $43 \%$ dari rotan utuh. Penghitungan dilakukan terhadap luasan penampang rotan batang (lingkaran) dan rotan balok (segi empat) yang dilakukan seperti berikut:

Jika diameter rotan adalah $3 \mathrm{~cm}$, $\mathrm{L}=\pi^{*} \mathrm{r}$

Luas $\mathrm{O}=22 / 7 *(1,5 \mathrm{~cm})=7,07 \mathrm{~cm}$

Luas $\square=2 * 2=4 \mathrm{~cm}$

Sisa bahan baku $=7,07-4=3.04$

Maka, persentase sisa bahan baku $=3,04$ / $7,07 * 100 \%=43 \%$
Namun saat ini, sudah ada penelitian yang memanfaatkan sisa bahan baku atau limbah rotan (serbuk atau potongan serat rotan) menjadi sebuah modul atau produk. Sehingga sisa bahan baku pembuatan bilah rotan berbentuk silinder astor dapat dijadikan :

- Material Komposit yang menggunakan serbuk rotan yang dipres dan direkatkan sedemikian rupa dengan ketebalan tertentu yang dapat dimanfaatkan sebagai material mebel (Yusuf 2016).

- Modul berbentuk silinder atau twister yang materialnya terbuat dari sisa bahan pembuatan bilah rotan.

C. Proses Desain

Pra eksperimen dilakukan dengan proses membuat skenario dalam pembuatan modul twister ini. Skenario tersebut melingkupi tata cara pembuatan modul twister menggunakan mesin, juga perancangan ukuran diameter cetakan, silinder, dan rotan, serta ketebalan bilah rotan. Namun, pada saat berdiskusi dengan pengrajin dilapangan, didapatkan beberapa hambatan teknis, yaitu tidak tersedianya mesin yang lengkap dan tidak tersedianya berbagai cetakan dengan ukuran yang rencanakan. Maka, dibentuk sebuah solusi dengan menggunakan teknik manual (tanpa mesin) untuk menciptakan modul twister ini, dan ukuran silinder pun tetap sesuai dengan rancangan semula yaitu dengan menggunakan berbagai ukuran cetakan bambu yang berbeda. Setelah melewati proses pra eksperimen, maka eksperimen dilanjutkan dengan berbagai tahapan, yaitu : 
Alivia Syam, Andar Sriwarno, Prabu Wardono, Pengembangan Desain Struktur Silinder Bilah Rotan Dengan Teknik Lilit

Tabel 1. Proses Tahapan Pembuatan Silinder Twister

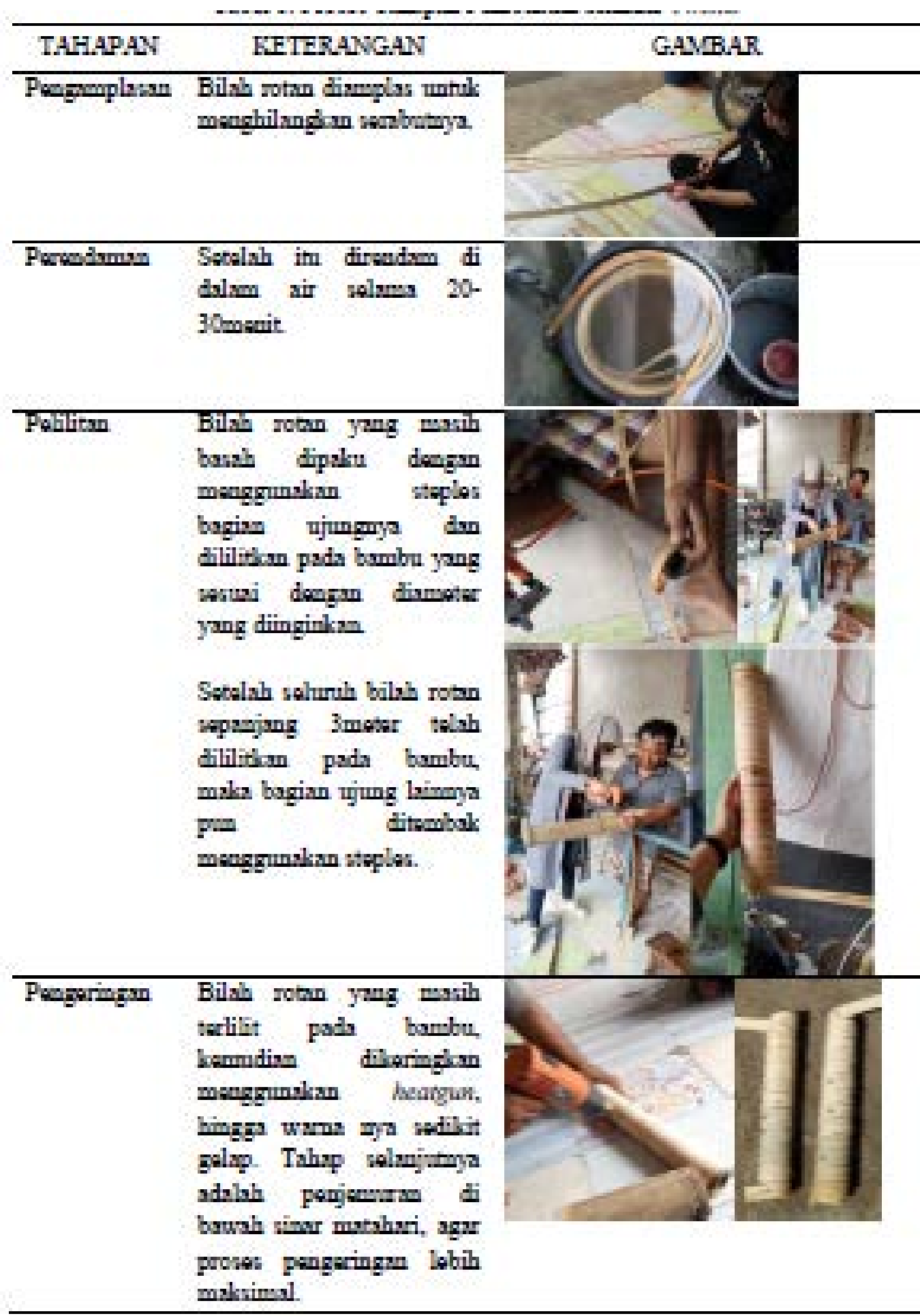


Vol. 5, No. 2, April 2018

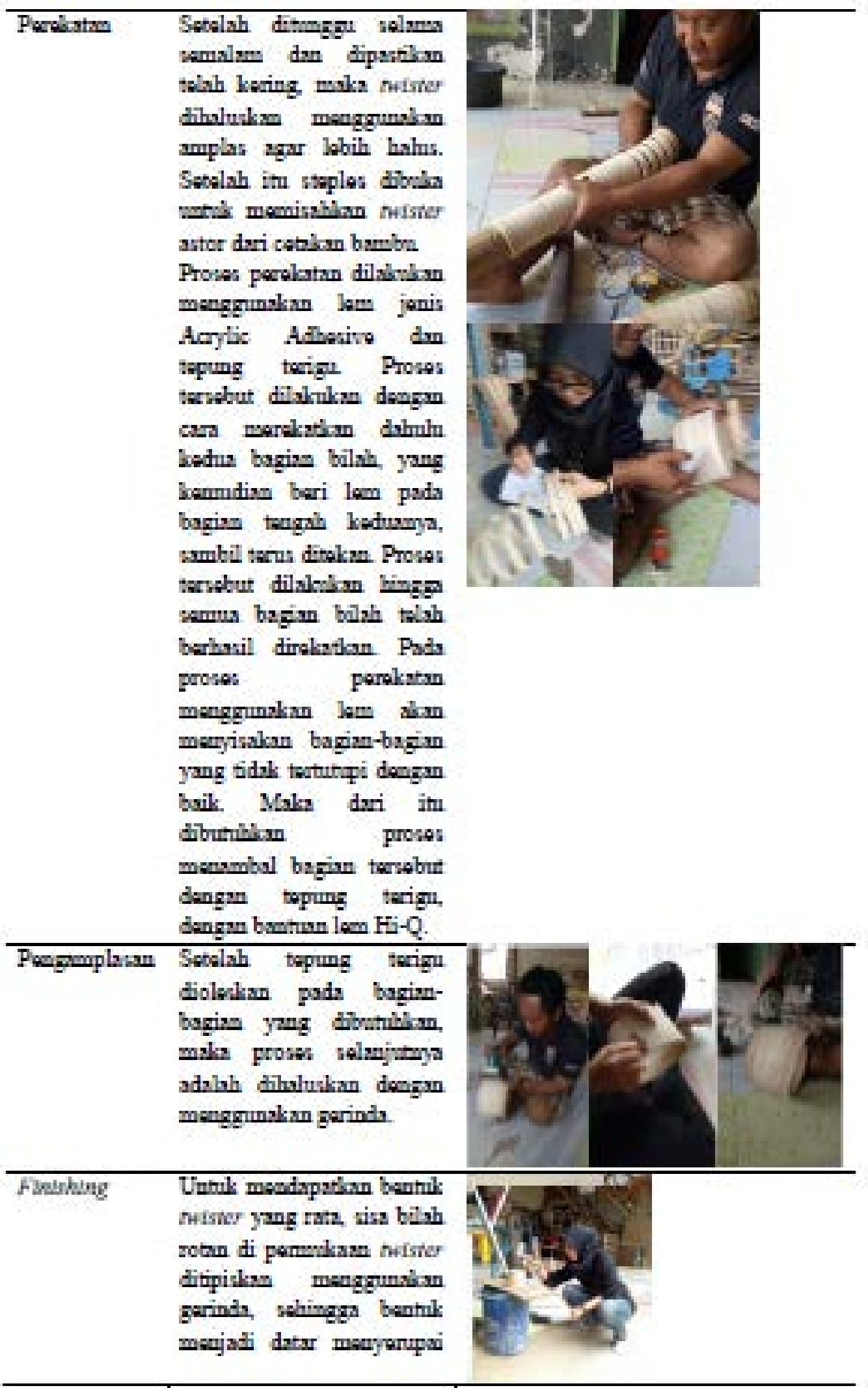




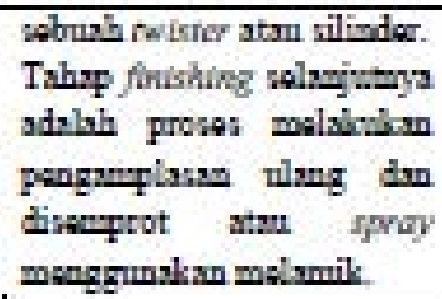

Dari beberapa tahapaneksperimen proses di atas, didapatkan sebuah modul yang berbentuk seperti silinder atau twister. Dari beberapa ukuran diameter twister yang dibuat, terdapat satu modul yang difinising dan yang lain dibiarkan tanpa perlakuan finishing. Berikut adalah hasil dari eksperimen penelitian yang telah dilakukan.

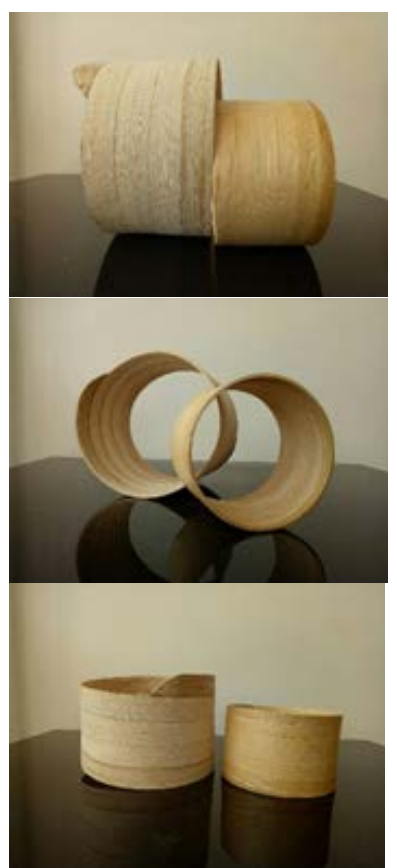

Gambar 3. Twister atau Modul Silinder (kiri unfinished)

\section{KEPUTUSAN DESAIN}

Tumbuhan rotan memiliki bagian-bagian yang seluruhnya dapat dimanfaatkan oleh manusia, seperti batang, buah, daun, dan akar (Jasni, Kalima, Damayanti, 2012). Namun batang rotan adalah hasil paling penting dari rotan, dan merupakan bagian rotan yang telah dihilangkan bagian 28 pelepah dan daunnya (Mulyatno dan Jokosisworo, 2008). Dari berbagai eksperimen yang telah dilakukan di Indonesia, batang merupakan bagian rotan yang paling sering digunakan dengan berbagai macam perlakuan dan metode. Oleh sebab itu, dapat dikatakan bahwa bagian rotan yang memiliki potensi paling besar untuk dieksperimenkan adalah batangnya.

Berbagai produk rotan yang selama ini beredar di pasaran, masih jarang yang menggunakan bilah rotan sebagai bahan dasarnya. Hal tersebut terlihat pada bentuk rotan yang diterapkan pada berbagai produk rotan, seperti kursi, meja, mainan anak, dan lain-lain. Sehingga dengan masih sedikitnya pihak yang mengolah bilah rotan, maka penelitian ini berfokus pada mengembangkan bilah rotan menjadi sebuah struktur atau bentuk baru, yang mengedepankan teknik lilit dan bending.

\section{KESIMPULAN}

A. Kesimpulan

Hasil yang didapatkan adalah sebuah pembaruan di modul produk rotan yang tidak menampilkan wajah asli rotan, melainkan visual baru yang mampu memberikan alternatif identitas lain, yaitu bilah rotan yang berbentuk pipih tidak seperti wajah asli rotan yg berbentuk lingkaran. Bilah rotan tersebut apabila dikombinasikan dengan teknik twist bending, mampu menahan beban karena bentuk yang dihasilkan adalah menyerupai silinder. Sehingga output dari penelitian ini diharapkan mampu menjadi dasar desain untuk pembuatan produk rotan yang lebih bervariasi. 
B. Saran

Dari eksperimen yang telah dilakukan terdapat beberapa saran, yaitu :

- Modul silinder atau twister ini berpeluang untuk dapat dibuat dari rotan yang berkualitas lebih rendah dari rotan Manau, sehingga dapat meningkatkan kualitas rotan-rotan tersebut.

- Membuat pengembangan lain dengan menggunakan cetakan yang memiliki bentuk lain, seperti segitiga atau segiempat.

- Membuat pengembangan lain dari twister dengan mengkombinasikannya dengan material lain.

\section{DAFTAR RUJUKAN}

Kalima, Titi., Jasni, M. (2012) : Atlas Rotan Indonesia. Bogor : Kementrian Kehutanan Badan Penelitian dan Pengembangan Kehutanan.

Marizar, Eddy. (2007) : Rotan dan Material Unik. Jakarta : PT Gramedia.

Mulyatno I., Jokosisworo S. (2008) : Analisa Teknis Penggunaan Serat Kulit Rotan Sebagai Penguat Pada Komposit Polimer Dengan Matriks. Kapal, Vol. 5, No.3. 173-180.

Tjiasmanto, Brian., Santosa, Adi., Ardianto, Okta. (2017) : Perancangan Modular Panel Dekoratif Berbahan Dasar Rotan Untuk Interior Bangunan Komersial. JURNAL INTRA Vol. 5, No. 2, 286-295.

Triwahyuni, Artha. (2014) : Dampak Kebijakan Pembatasan Ekspor Rotan terhadap Ekspor Produk Rotan Indonesia Kelima Negara Pengimpor Produk Rotan Periode 1986 2012. FEUI, E20, 011.

Yusuf. (2016) : Studi Pemanfaatan Rotan Sisa Industri untuk Pengembangan Material Komposit sebagai Penunjang Desain Furnitur dan Interior. Tesis : Fakultas Seni Rupa dan Desain Institut Teknologi Bandung.

\section{Website :}

Analisis Kebijakan Ekspor : Evaluasi Kebijakan Pelarangan Ekspor Rotan. Diunduh pada http: //www.kemendag.go.id/files/pdf/2015/02/02/evaluasi-kebijakan-pelarangan-1422851758.pdf. Diakses tanggal 10 Mei 2017.

Making Indonesia 4.0. Diunduh pada www.kemenperin.go.id/download/18384. Diakses tanggal 10 Agustus 2018.

Perkembangan Ekspor Kelompok Furnitur Dari Rotan Atau Bambu. Diunduh pada http:// kemenperin.go.id/statistik/barang.php?ekspor $=1 \&$ kode $=202031002$. Diakses tanggal 20 Februari 2018. 